\title{
Pengaruh Opini Audit dan Audit Delay Pada Auditor Switching dengan Karakteristik Komite Audit Sebagai Pemoderasi
}

\author{
Gusti Ngurah Made Dwiphayana ${ }^{1}$ \\ Fakultas Ekonomi dan Bisnis \\ Universitas Udayana, Indonesia. \\ Email: dwiphayana06@gmail.com
}

\author{
I Dewa Gede Dharma Suputra ${ }^{2}$ \\ Fakultas Ekonomi dan Bisnis \\ Universitas Udayana, Indonesia.
}

\begin{abstract}
ABSTRAK
Penelitian ini bertujuan untuk menguji pengaruh opini audit dan audit delay pada auditor switching dan bagaimana karakteristik komite audit mampu memoderasi pengaruh opini audit dan audit delay pada pergantian auditor. Penentuan sampel penelitian menggunakan metode purposive sampling dengansampel sebanyak 120 perusahaan. Teknik analisis data yang digunakan adalah analisis regresi logistik dan Moderated Regression Analysis (MRA).Hasil penelitian menunjukkan opini audit berpengaruh negatif pada pergantian auditor, sedangkan audit delay berpengaruh positif pada pergantian auditor. Karakteristik komite audit mampu memperlemah pengaruh positif audit delay pada auditor switching. Namun karakteristik komite audit ini tidak mampu memoderasi pengaruh opini audit pada auditor switching.
\end{abstract}

Kata Kunci: Opini audit, audit delay, komite audit, auditor switching.

\section{The Effect of Audit Opinion and Audit Delay on Auditor Switching with the Characteristics of the Audit Committee as Moderating}

\begin{abstract}
This study aims to examine the effect of audit opinion and audit delay on auditor switching and how the characteristics of the audit committee are able to moderate the influence of audit opinion and audit delay on auditor turnover. Determination of sample using purposive sampling method with samples of 120 companies. The data analysis technique used is logistic regression analysis and Moderated Regression Analysis (MRA). The results of the study show that audit opinion has a negative effect on auditor turnover, while audit delay has a positive effect on auditor turnover. The characteristics of the audit committee are able to weaken the positive influence of audit delay on auditor switching. But the characteristics of the audit committee are not able to moderate the influence of the audit opinion on the auditor switching.
\end{abstract}

Keywords: Audit opinion, audit delay, audit committee, auditor switching.

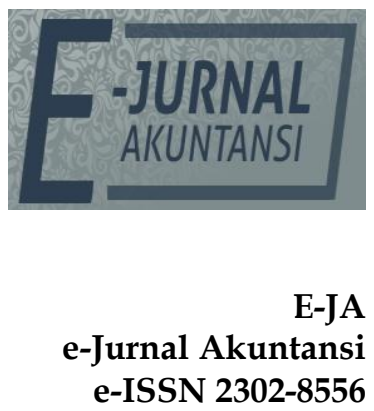

Denpasar, Vol. 28 No. 3

September 2019 Hal. 1965-1983

Artikel masuk: 20 Juni 2019

Tanggal diterima: 27 Agustus 2019 


\section{PENDAHULUAN}

Laporan keuangan perusahaan merupakan sarana yang digunakan untuk mengambil keputusan baik oleh pihak internal maupun eksternal perusahaan. Laporan keuangan perusahaan menyajikan berbagai informasi keuangan perusahaan selama kurun waktu tertentu serta akan memberikan informasi terkait dengan kondisi perusahaan secara aktual (Riyandari, 2017). Statement of Financial Accounting Concepts (SFAC) No.1 menjelaskan bahwa tujuan utama dari laporan keuangan adalah untuk menyediakan informasi yang berguna bagi para pengguna laporan keuangan dalam pembuatan keputusan bisnis dan ekonomi. Mengacu pada SFAC tersebut laporan keuangan yang diterbitkan oleh perusahaan haruslah dapat dirpercaya, serta disajikan secara wajar sesuai dengan standar yang berlaku, agar informasi yang diberikan tidak menyesatkan, mengingat banyaknya pihak-pihak yang berkepentingan akan laporan keuangan tersebut.

Komunikasi data keuangan dan data ekonomi suatu perusahaan menjadi penting bagi investor (principal) dan manajemen perusahaan (agent). Adanya perbedaan kepentingan dan asimetri informasi diantara kedua pihak tersebut, menyebabkan adanya konflik keagenan yang dijelaskan dalam teori agensi (Paramita, 2015). Hubungan keagenan dikenal sebagai kontrak antara dua belah pihak untuk melaksanakan suatu pekerjaan. Ketidak asimetrisan informasi antara pihak satu dengan pihak yang lainnya ini yang harus dibantu dengan adanya mediator (Setiawan, 2006). Karena adanya konflik kepentingan serta asimetri informasi antara agent (manajemen) dan principal yang dijelaskan dalam teori agensi tersebut, akan menyebabkan kemungkinan terjadinya manipulasi terhadap laporan keuangan suatu perusahaan yang dilakukan oleh agent agar menguntungkan bagi dirinya (Peranian, 2018).

Untuk meningkatkan keandalan dan relevansi, serta untuk menghindari kesalahan yang mungkin terjadi dalam laporan keuangan suatu perusahaan, juga untuk mengatasi permasalahan dari agency problem, diperlukan seorang auditor sebagai pihak ketiga untuk mengaudit atau memeriksa serta mengawasi laporan keuangan tersebut. Standar Audit 200 (paragraf 3) menyatakan, tujuan dilakukannya suatu audit laporan keuangan adalah untuk meningkatkan keyakinan para pengguna laporan keuangan. Proses audit yang dilakukan oleh auditor independen akan mampu meningkatkan nilai informasi dari laporan keuangan perusahaan.

Auditor di dalam memeriksa laporan keuangan haruslah bersifat objektif dan independen serta sesuai dengan standar yang berlaku, namun demikian, masih ada auditor yang tidak independen dalam melaksanakan proses audit. Hal ini dapat dilihat dari beberapa kasus terkait kecurangan laporan keuangan yang melibatkan perusahaan dan auditor seperti kasus Enron di Amerika Serikat, serta beberapa kasus kecurangan yang terjadi di dalam negeri seperti kasus Bank Lippo dan kasus PT. Kimia Farma.

Fenomena mengenai pergantian auditor mulai muncul ketika kasus Enron di Amerika terungkap. Independensi auditor mulai diragukan setelah terjadinya kasus Enron pada Desember 2001 tersebut. Kasus Enron Corporation yang melibatkan KAP Arthur Andersen tersebut menimbulkan pertanyaan apakah sebenarnya penyebab kegagalan tersebut. Banyak pihak berpendapat 
bahwa hal ini disebabkan adanya hubungan kerja yang panjang antara KAP dan klien selama 16 tahun sejak 1985. Perikatan kerja yang terlalu lama menyebabkan suatu risiko excessive familiarity (keakraban yang berlebihan), sehingga dapat mempengaruhi objektivitas dan independensi KAP (Nikmah, 2014). Kasus ini memperlihatkan bahwa adanya indikasi auditor melakukan kerjasama dengan pihak yang diaudit untuk melakukan kecurangan dengan memanipulasi laporan keuangan yang ada. Hubungan yang panjang antara auditor dan klien ini menyebabkan auditor cenderung kehilangan independensinya sehingga menimbulkan keraguan terhadap kualitas dari laporan keuangan yang diaudit.

Bercermin dari kasus tersebut, untuk mempertahankan keandalan laporan keuangan perusahaan dan juga independensi dari auditor maka perusahaan diwajibkan untuk melakukan pergantian auditor atau auditor switching. Auditor Switching merupakan pergantian auditor atau KAP yang dialakukan oleh suatu perusahaan yang dapat terjadi karena aturan pemerintah ataupun karena keingginan dari perusahaan sendiri. Auditor switching diperlukan karena masa perikatan audit yang lama dengan klien akan mengakibatkan turunnya sikap independensi auditor dan akan terikat secara emosional serta menimbulkan masalah mengenai eskalasi komitmen terhadap keputusan yang buruk dari seorang auditor (Giri, 2010).

Di Indonesia, peraturan mengenai rotasi audit sudah diatur sejak tahun 2002 yang tercantum pada Keputusan Menteri Keuangan Nomor 423/KMK.06/2002 dan KMK Nomor 359/KMK/.06/2003 yang telah direvisi dengan Peraturan Menteri Keuangan Nomor 17/PMK.01/2008 tentang jasa akuntan publik mengenai pembatasan masa pemberian jasa audit oleh KAP selama maksimal 6 tahun berturut-turut dan auditor selama 3 tahun berturutturut. Peraturan selanjutnya diperbaharui oleh Peraturan Pemerintah No 20 Tahun 2015 berlaku mulai 6 April 2015. Terdapat aturan baru yang menyatakan jika perusahaan meempergunakan KAP tidak perlu diadakan pergantian KAP, namun perusahaan wajib melakukan pergantian auditor jika masa perikatan paling lama 5 tahun bertutut-turut. Perusahaan diberikan kesempatan untuk melakukan perikatan kembali pada AP yang sama jika AP tidak melakukan proses audit pada laporan keuangan laporan keuangan perusahaan selama 2 tahun buku berturut turut.

Pergantian auditor yang dilakukan perusahaan tidak hanya dilakukan karena adanya aturan tersebut, melainkan juga bisa terjadi karena danya faktor lain yang mendorong perusahaan melakukan pergantian auditor. Menurut AlAzhar L (2015), terdapat 2 jenis pergantian auditor (auditor switching) yaitu pergantian sukarela (voluntary) dan pergantian wajib (mandatory). Tisna dan Suputra, 2017, mengatakan pergantian dari seorang auditor atau Kantor Akuntan Publik (KAP) yang disebabkan karena aturan yang ditetapkan oleh pemerintah ataupun karena kehendak perusahaan itu sendiri disebut dengan auditor switching. Auditor switching dapat disebut mandatory atau wajib apabila pergantingan auditor disebabkan karena pencapaian yang maksimal secara berturut-turut jumlah tahun masa perikatan. Sedangkan voluntary terjadi apabila pergantian auditor dilakukan secara sukarela atau tidak berdasarkan peraturan yang berlaku. 
Kasus PT Inovisi Infracom Tbk (INVS) yang mendapat sanksi penghentian sementara (suspen) perdagangan saham oleh PT Bursa Efek Indonesia (BEI). Sanksi ini diberikan karena ditemukan banyak kesalahan di laporan kinerja keuangan perusahaan kuartal III-2014. Perseroan pun menunjuk kantor akuntan publik (KAP) yang baru untuk melakukan audit terhadap laporan keuangan perusahaan tahun buku 2014. Perusahaan inevstasi tersebut menunjuk Kreston International (Hendrawinata, Eddy Siddharta, Tanzil, dan Rekan) untuk mengaudit laporan kinerja keuangannya. Sebelumnya Inovisi memakai KAP Jamaludin, Ardi, Sukimto, dan Rekan pada audit laporan keuangan 2013. "Pergantian KAP dilakukan agar kualitas penyampaian laporan keuangan Perseroan dapat meningkat sesuai dengan ketentuan dan standar yang berlaku," kata Sekretaris Perusahaan Inovisi, Dwiwati Riandhini. Perdagangan saham Inovisi masih dihentikan sejak Jumat 13 Februari 2015. BEI menemukan ada delapan kesalahan dalam laporan keuangan sembilan bulan 2014. Aksi pembekuan saham ini diprotes investor karena harga saham Inovisi tidak berubah dan investor tidak bisa melepas maupun membeli saham Inovisi. Bahkan ada investor ritel yang dananya nyangkut Rp. 70 juta di saham Inovisi tanpa bisa berbuat apa-apa. (Detik Finance, "Laporan Keuangan Bermasalah, Inovisi Ganti Auditor", 2015 dalam http:/ / m.detik.com).

Kasus ini menunjukkan bahwa PT Inovisi melakukan pergantian auditor bukan karena peraturan yang ada melainkan karena PT Inovisi ingin agar kualitas penyampaian laporan audit atas laporan keuangan perusahaannya dapat meningkat dan sesuai dengan standar yang berlaku. Pergantian auditor secara sukarela juga bisa terjadi karena dipengaruhi oleh beberapa faktor seperti biaya yang tidak sesuai, tidak puas dengan KAP lama, kualitas audit, reputasi dari auditor, terjadinya audit delay, pemberian opini yang tidak sesuai dengan keinginan klien serta terjadinya krisis keuangan yang dialami oleh perusahaan. Adapun faktor-faktor yang akan diteliti pada penelitian ini yaitu opini audit dan audit delay serta karakteristik dari komite audit.

Opini audit bisa menjadi salah satu pemicu terjadinya pergantian auditor. Akuntan publik atau auditor bertanggung jawab dalam melakukan penilaian terhadap kewajaran laporan keuangan. Penilaian yang diberikan oleh auditor terhadap laporan keuangan adalah melalui pendapat yang diberikan setelah melakukan proses audit (Arma, 2013). Pendapat yang diberikan oleh auditor pada laporan keuangan setelah melakukan pemeriksaan kewajaran laporan keuangan tersebut dikatakan sebagai opini audit. Opini atau pendapat yang diberikan oleh seorang auditor ini sangat penting sebagai dasar pertimbangan bagi para pemakai laporan keuangan untuk mengambil sebuah keputusan (Alansari, 2016).

Manajemen dari perusahaan tentu saja menginginkan agar perusahaannya mendapat opini audit wajar tanpa pengecualian. Namun tidak jarang juga seorang auditor mengeluarkan opini audit modifikasi mengenai going concern ketika merasa bahwa terdapat keraguan atas kelangsungan hidup perusahaan. Ramantha (2014) menjelaskan pemberian opini audit going concern yang dilakukan auditor kepada perusahaan, menjelaskan tentang keraguan atas kondisi perusahaan yang akan menyebabkan perusahaan terganggu. Pengeluaran opini audit going concern adalah hal yang tidak diharapkan oleh 
perusahaan karena dapat berdampak pada kemunduran harga saham, kesulitan dalam meningkatkan modal pinjaman, ketidakpercayaan investor, kreditor, pelanggan, dan karyawan terhadap manajemen perusahaan. Perussahaan akan cenderung untuk mengganti auditor ketika mendapat opini yang tidak sesuai dengan yang diinginkan perusahaan yaitu opini wajar tanpa pengecualian (unqualified).

Sama seperti opini audit, audit delay juga merupakan salah satu faktor yang mempengaruhi terjadinyapergantian auditor. Audit delay adalah lamanya waktu yang dibutuhkan oleh auditor dalam menghasilkan laporan audit atas laporan keuangan perusahaan terhitung dari tanggal tutup tahun sampai tanggal opini audit diserahkan dan ditandatangani (Farida, 2016). Lamanya audit delay yang terjadi akan menyebabkan laporan keuangan terlambat diberikan kepada BAPEPAM LK dan laporan keuangan akan terlambat untuk dipublikasikan kepada masyarakat umum dan pihak-pihak yang berkepentingan. Keterlambatan tersebut akan memberikan sinyal negatif kepada para pihak yang berkepentingan bahwa keterlambatan tersebut menunjukkan bahwa perusahaan sedang mengalami kondisi yang kurang baik (Robbitasari dan Wiratmaja, 2013). Oleh karena itu perusahaan yang mengalami audit delay cenderung akan melakukan pergantian auditor pada periode berikutnya agar laporan keuangan tidak mengalami keterlambatan publikasi serta untuk memperoleh kembali kepercayaan dari pihak-pihak yang berkepentingan terutama investor (Verawati dan Wirakusuma, 2016).

Pergantian auditor yang dilakukan oleh perusahaan tidak terlepas dari peran serta manajemen. Saat auditor mengeluarkan opini audit yang tidak diinginkan oleh manajemen atau perusahaan, manajemen cenderung akan mencari auditor baru yang lebih lunak untuk mengganti auditor sebelumnya. Begitu juga ketika perusahaan mengalami audit delay manajemen juga cenderung untuk mengganti auditor agar hal yang sama tidak akan terjadi lagi. Stocken (2000) dalam Srimindarti (2006), menyatakan jika waktu yang dibutuhkan auditor untuk menyelesaikan auditnya terlalu lama perusahaan akan terlambat untuk menyampaikan laporan keuangannya ke BAPEPAM LK dan hal ini akan mempengaruhi manajemen untuk melakukan pergantian auditor.

Berdasarkan kondisi di atas, peran dan karakteristik dari komite audit yang dimiliki perusahaan dipercaya dapat menghalangi usaha manajemen dalam melakukan pergantian auditor. Komite audit diharapkan dapat menjaga integritas proses pelaporan audit karena tugas dalam memberikan rekomendasi penunjukan dan penggantian KAP merupakan bagian penting dari peran, tanggung-jawab dari keberadaan komite audit itu sendiri (Lennox, 2002). Tugas komite audit perlu ditekankan kembali agar campur tangan manajemen dalam penentuan auditor eksternal dapat dihindari, sehingga independensi auditor dapat terjaga (Nuratama, 2011). Keberadaan komite audit sebagai mekanisme corporate governance dipercaya dapat mengurangi kecenderungan pergantian auditor karena manajemen ataupun pemegang saham yang memiliki kendali tidak akan memiliki wewenang campur tangan dalam membuat keputusan pemilihan auditor (Lin dan Liu, 2010). 
Komite audit adalah salah satu komponen yang berperan penting di dalam penerapan good corporate governance (GCG). Komite audit diharapkan dapat menjaga sistem pengendalian internal yang memadai serta melakukan monitoring terhadap kinerja auditor eksternal untuk mewujudkan tata kelola perusahaan yang baik (Rustiarini, 2012). Peranan komite audit dalam menjamin kualitas pelaporan keuangan perusahaan diharapkan dapat menjadi solusi untuk mencegah terjadinya skandal keuangan perusahaan. Komite audit adalah mekanisme corporate governance internal yang diharapkan dapat melakukan supervisi atau pengawasan atas proses pelaporan keuangan dan proses audit. Komite audit berperan untuk membantu dewan komisaris dalam memberikan pandangan mengenai masalah-masalah yang berhubungan dengan kebijakan akuntansi dan keuangan,melakukan pengawasan atas fungsi pengendalian intern dan eksternal perusahaan, serta merekomendasikan penunjukkan dan penggantian auditor eksternal (Merawati, 2014).

Terdapat beberapa karakteristik komite audit yang akan sangat menentukan keberhasilan komite audit dalam melaksanakan tugas dan tanggung jawabnya untuk perusahaan. Menurut (Prasetyo, 2016), di dalam menjalankan tugas dan fungsinya, karakteristik- karakteristik yang dimiliki komite audit tersebut akan menunjukkan apakah tugas komite audit tersebut telah berjalan efektif atau belum. Karakteristik komite audit tersebut dapat ditunjukkan oleh indpendensi komite audit, jumlah rapat yang dilakukan oleh komite audit dalam satu tahun, masa jabatan dari para anggota komite audit yang didasarkan pada berapa lama telah menjadi komite audit, serta keahlian di bidang akuntansi dan keuangan yang dimiliki oleh anggota komite audit.

Karakteristik komite audit dalam penelitian ini diasosiasikan berdasarkan karakteristik keahlian akuntansi dan keuangan komite audit, hal ini merujuk pada aturan yang dikeluarkan oleh Task Force Komite Audit yang mengatur bahwa anggota komite audit harus independen, memiliki kompetensi dalam bidang akuntansi dan keuangan serta berpengalaman dalam implementasi good corporate governance. Kep-643/BL/2012 menjelaskan bahwa komite audit sekurang kurangnya memiliki 3 (tiga) anggota dan wajib memiliki paling kurang 1 (satu) anggota yang memiliki latar belakang pendidikan dan keahlian bidang akuntansi dan keuangan. Kompetensi ini menunjukan adanya pencapaian dan pemeliharaan suatu tingkatan pemahaaman dan pengetahuan yang dimiliki seorang anggota komite dalam melaksanakan tugasnya (Purwoningsih, 2016). Anggota komite audit yang memiliki keahlian akuntansi dan keuangan juga akan lebih efektif mengawasi pelaporan keuangan perusahaan dan proses audit (Owens-Jackson et al., 2009) sehingga terjadinya pergantian auditor akibat opini audit maupun audit delay juga dapat dicegah.Selain itu kompetensi yang dimiliki oleh komite audit juga sangat penting mengingat salah satu tugas komite audit menurut SK Bapepam dan LK No Kep 29/PM/2004, adalah melakukan penelaahan atas informasi keuangan yang akan dikeluarkan perusahaan dan melakukan penelaahan atas pemeriksaan auditor eksternal. 
Oleh karena itu penelitian ini akan memosisikan karakteristik komite audit yang diproksikan dengan keahlian akuntansi dan keuangan komite audit sebagai variabel pemoderasi untuk meneliti pengaruh opini audit dan audit delay pada auditor switching. Karakteristik komite audit ini diperkirakan akan dapat memperkuat atau memperlemah pengaruh dari opini audit dan adit delay pada pergantian auditor. Penelitian dari (Artawijaya dan Putri, 2016) menunjukkan bahwa keahlian akuntansi dan keuangan komite audit berpengaruh pada kecenderungan berkurangnya pergantian auditor. Hasil penelitian dari (Merawati et al., 2013) juga menunjukan bahwa karakteristik keahlian akuntansi dan keuangan komite audit mampu memoderasi pengaruh penerbitan opini audit going concern pada kemungkinan perusahaan melakukan pergantian auditor.

Motivasi dari penelitian ini adalah masih adanya kasus manipulasi akuntansi yang terjadi antara perusahaan dan auditor seperti kasus yang telah dijelaskan diatas, serta adanya inkonsistensi dari hasil peneliti terdahulu terkait dengan topik ini membuat penelitian dengan dasar auditor switching ini masih menarik untuk dilakukan. Hasil penelitian Pratini (2013) menunjukan bahwa opini audit tidak berpengaruh pada pergantian auditor. Sedangkan Tisna dan Suputra (2017), menyatakan bahwa opini audit berpengaruh pada pergantian auditor. Hal ini didukung oleh hasil penelitian dari Permata dan Astika (2018), yang menunjukkan bahwa opini audit berpengaruh positif pada keputusan perusahaan dalam melakukan pergantian auditor. Begitu juga dengan faktor audit delay terdapat ketidakkonsistenan hasil penelitian. Farida (2016), mengungkapkan bahwa audit delay berpengaruh positif terhadap auditor switching. Sedangkan Purwoningsih (2016) mengatakan bahwa audit delay tidak berpengaruh pada pergantian auditor. Ketidaksamaaan hasil penelitian ini juga menjadi salah satu faktor mengapa penulis melakukan penelitian dengan mengankat topik ini.

Teori keagenan, mengkehendaki adanya peran pihak ketiga yang memiliki sikap independen sebagai mediator antara pihak prinsipal dan agen. Fungsi dari pihak ketiga ini untuk memonitor perilaku manajer sebagai agen dan memastikan agen sudah bertindak sesuai dengan kepentingan prinsipal (Adhiputra, 2015). Pihak yang mampu menjembatani kepentingan pihak prinsipal dengan pihak agen sebagai bentuk pertanggungjawaban pihak agen kepada pihak prinsipal adalah auditor. Pihak manajer menerima opini atas kewajaran laporan keuangan dari auditor yang merupakan tugas dari auditor yang keandalannya dapat dilihat dari kualitas audit yang dihasilkan.

Opini merupakan pernyataan pendapat yang diberikan oleh auditor dalam menilai kewajaran perjanjian laporan keuangan perusahaan yang diauditnya. Opini audit merupakan pernyataan atas suatu asersi yang dikeluarkan oleh auditor (Arma, 2013). Setelah mengaudit laporan keuangan klien, auditor akan memberikan opininya terhadap laporan keuangan tersebut. Opini yang diberikan oleh auditor ini dapat mempengaruhi pengambilan keputusan yang dilakukan oleh para pihak yang berkepentingan. Pihak-pihak tersebut akan merasa lebih yakin kepada perusahaan yang mendapat opini wajar tanpa pengecualian pada laporan keuangannya. Jika auditor tidak dapat memberikan opini sesuai yang diharapkan, perusahaan cenderung akan 
melakukan pergantian auditor pada tahun berikutnya dengan tujuan untuk memperoleh opini yang lebih baik.

Beberapa penelitian berhasil menunjukkan bahwa opini audit merupakan salah satu pemicu terjadinya pergantiaan auditor. Penelitian dari Chow dan Rice (1982) telah berhasil membuktikan bahwa opini wajar dengan pengecualian (qualified audit opinion) merupakan salah satu determinan yang memicu pergantian auditor. Penelitian dari Putra dan Suryanawa (2016) juga menemukan bahwa opini audit berpengaruh negatif terhadap auditor switching. Perusahaan akan cenderung untuk melakukan pergantian auditor ketika opini audit yang diberikan oleh auditor tidak sesuai dengan apa yang diharapkan oleh klien. Hasil yang sama juga didapat dari penelitian Wahyuningsih dan Suryanawa (2012) yang menyatakan bahwa opini audit berpengaruh negatif pada auditor switching.

Berdasarkan uraian diatas, hipotesis yang dapat dikembangkan adalah: $\mathrm{H}_{1}$ : Opini audit berpengaruh negatif pada auditor switching.

Audit delay adalah lamanya hari yang dibutuhkan auditor untuk menyelesaikan pekerjaan auditnya, yang diukur dari tanggal penutupan tahun buku hingga tanggal diterbitkannya laporan keuangan audit (Verawati dan Wirakusuma, 2016). Chrisanty (2010) terkait dengan teori sinyal menyatakan perusahaan yang berkualitas baik nantinya akan memberi sinyal dengan cara menyampaikan laporan keuangannya dengan tepat waktu. Keterlambatan penerbitan laporan audit akan menyebabkan ketidakpastian pergerakan harga saham perusahaan. Investor dapat mengartikan keterlambatan penerbitan laporan audit sebagai indikasi bahwa perusahaan memiliki bad news sehingga tidak segera menyampaikan laporan keuangannya (Febrianty, 2011).

Penelitian dari Robbitasari dan Wiratmaja (2013), menemukan bahwa audit delay secara signifikan berpengaruh pada auditor switching. Pempublikasian laporan keuangaan yang mengalami keterlambatan akan mengakibatkan para investor pemegang saham merasa curiga dan menilai negatif bahwa perusahaan tersebut sedang mengalami masalah. Terjadinya keterlambatan dari pempublikasian laporan auditan menyebabkan perusahaan akan mengganti auditornya karena perusahaan tidak menginginkan keterlambatan publikasi akan terulang pada tahun berikutnya. Penelitian dari Farida (2016) serta Pawitri dan Yadnyana (2015) juga menunjukkan hasil yang sama, yaitu audit delay berpengaruh secara signifikan terhadap auditor switching. berikut:

Dari penjelasan tersebut, maka dapat disusun sebuah hipotesis sebagai $\mathrm{H}_{2}$ : Audit delay berpengaruh positif terhadap auditor switching.

Konflik dalam teori agensi antara manajer dan pemegang saham sering membuat manajemen puncak perusahaan mengambil keputusan tidak dalam kepentingan terbaik dari pemegang saham (Jensen dan Meckling, 1976) . Tanpa adanya pengawasan yang efektif, manajemen perusahaan akan menyimpang dari tugasnya, yang akan berdampak buruk terhadap kinerja perusahaan. Dalam teori agensi dijelaskan bahwa masing-masing individu termotivasi oleh kepentingan dirinya sendiri sehingga akan menimbulkan konflik kepentingan antara pihak principal dan agent, yang sering disebut sebagai agency problem (Jensen dan Meckling, 1976). Salah satu cara yang dapat diterapkan oleh 
perusahaan untuk mencegah dan mengurangi agency problem tersebut adalah dengan menerapkan mekanisme corporate governance, yang salah satunya adalah dengan keberadaan dari komite audit (Adhiputra, 2015).

Manajemen cenderung untuk menghindari perusahaanya menerima opini audit selain wajar tanpa pengecualian. Hal ini dikarenakan opini selain wajar tanpa pengecualian akan memberikan dampak buruk bagi perusahaan. Opini yang diberikan oleh auditor sangat penting sebagai dasar pertimbangan bagi para pihak berkepentingan untuk mengambil suatu keputusan (Kristiana, 2012). Ketika perusahaan menerima opini audit selain wajar tanpa pengecualian akan menyebabkan menurunnya kepercayaan publik kepada perusahaan. Sehingga hal ini menyebabkan manajemen berkeinginan untuk melakukan pergantian auditor pada tahun berikutnya untuk mendapat opini yang lebih baik dari sebelumnya (Tisna dan Suputra, 2017).

Berkaitan dengan hal tersebut, maka peran komite audit disini sangat diperlukan untuk menghindari kecenderungan manajemen untuk melakukan pergantian auditor. Perusahaan tentu saja selalu menginginkan agar mendapat wajar tanpa pengecualian dari auditor eksternal. Namun, ketika perusahaan menerima opini audit selain opini wajar tanpa pengecualian, perusahaan tidak selalu akan melakukan pergantian auditor. Komite audit dengan keahlian akuntansi dan keuangan dapat meminimalisir terjadinya pergantian auditor. DeZoort dan Salterio (2001) menemukan bahwa keahlian akuntansi dan keuangan yang dimiliki anggota komite audit dapat menganalisis kesalahan dan masalah yang berkaitan dengan prosedur dan standar akuntansi teknikal. Senada dengan hal tersebut, Owens-Jackson et al., (2009) juga menemukan bahwa keahlian akuntansi dan keuangan komite audit berpengaruh pada pergantian auditor. Hal ini dikarenakan komite audit yang lebih berpengalaman dalam bidang akuntansi dan keuangan akan lebih baik dalam mengawasi keputusankeputusan yang dibuat oleh manajemen.

Berdasarkan uraian tersebut, maka dapat dikembangkan sebuah hipotesis sebagai berikut.

$\mathrm{H}_{3}$ : Keahlian akuntansi dan keuangan komite audit memperlemah pengaruh opini audit pada auditor switching.

Lamanya audit delay yang terjadi akan menyebabkan laporan keuangan terlambat diberikan kepada BAPEPAM LK dan laporan keuangan akan terlambat untuk dipublikasikan kepada masyarakat umum dan pihak-pihak yang berkepentingan (Robbitasari dan Wiratmaja, 2013). Keterlambatan tersebut akan memberikan sinyal negatif kepada para pihak yang berkepentingan bahwa keterlambatan tersebut menunjukkan bahwa perusahaan sedang mengalami kondisi yang kurang baik. Oleh karena itu perusahaan yang mengalami audit delay cenderung akan melakukan pergantian auditor pada periode berikutnya agar laporan keuangan tidak mengalami keterlambatan publikasi serta untuk memperoleh kembali kepercayaan dari pihak-pihak yang berkepentingan terutama investor (Verawati dan Wirakusuma, 2016).

Dalam teori agensi dijelaskan bahwa masing-masing individu termotivasi oleh kepentingan dirinya sendiri sehingga akan menimbulkan konflik kepentingan antara pihak principal dan agent, yang sering disebut sebagai agency problem (Jensen dan Meckling, 1976). Salah satu cara yang dapat diterapkan oleh 
perusahaan untuk mencegah dan mengurangi agency problem tersebut adalah dengan menerapkan mekanisme corporate governance, yang salah satunya adalah dengan keberadaan dari komite audit. Komite audit merupakan salah satu komponen corporate governance yang berperan penting dalam proses pelaporan keuangan dengan cara mengawasi efektivitas kinerja auditor independen dalam proses pelaporan keuangan serta membantu tugas-tugas dari dewan komisaris. Sehingga dalam hal ini keberadaan komite audit yang memiliki kompetensi atau keahlian di bidang akuntansi dan keuangan sangat diperlukan. Terkait dengan auditor eksternal, komite audit memiliki tugas sebagai seorang mediator antara manajemen dengan auditor eksternal. Dengan kompetensi yang dimiliki oleh komite audit tersebut, fungsi dan peran dari komite audit ini akan menjadi lebih efektif.

Berkaitan dengan hal tersebut, jika komite audit dikaitkan dengan audit delay maka pengaruh yang diberikan seharusnya memperlemah pengaruh audit delay terhadap pergantian auditor. Hal ini dikarenakan kompetensi keuangan dan keahlian akuntansi yang dimiliki komite audit akan memberikan hasil analisis yang mencegah manajemen untuk mengganti auditor saat terjadinya audit delay. Hal ini berkaitan dengan reputasi perusahaan dan kepercayaan publik terhadap perusahaan. Dengan mengganti auditor saat terjadi audit delay akan memberikan sinyal yang negatif yang akan mengurangi kepercayaan publik terhadap perushaan.

Berdasarkan uraian tersebut, maka dapat disusun sebuah hipotesis sebagai berikut:

$\mathrm{H}_{4}$ : Keahlian akuntansi dan keuangan komite audit memperlemah pengaruh audit delay pada auditor switching

\section{METODE PENELITIAN}

Lokasi penelitian merupakan suatu tempat atau wilayah dimana penelitian tersebut akan dilakukan. Penelitian ini dilakukan pada perusahaan-perusahaan manufaktur yang terdaftar di Bursa Efek Indonesia (BEI) pada tahun 2013-2017, dengan mengakses situs www.idx.co.id untuk mendapatkan data-data perusahaan yang diperlukan.

Sektor manufaktur dipilih dengan alasan perusahaan manufaktur merupakan jenis usaha yang memiliki ruang lingkup yang luas (paling banyak terdaftar di $\mathrm{BEI})$, sehingga dianggap dapat mewakili keseluruhan emiten yang terdaftar di BEI dan diharapkan tingkat generalisasi temuan cukup tinggi. Serta untuk menghindari adanya industrial effect yaitu risiko industri yang berbeda antara satu sektor industri dengan sektor industri lainnya, yang dapat menyebabkan hasil penelitian menjadi luas dan tidak dapat menggambarkan objek secara detail. Selain itu perusahaan manufaktur cenderung tanggap dengan kondisi lingkungan sehingga mampu berkembang pesat serta periode tahun yang diteliti cenderung mencerminkan kondisi perekonomian yang stabil.

Populasi pada penelitian ini adalah perusahaan manufaktur yang telah terdaftar di Bursa Efek Indonesia (BEI) pada tahun 2013-2017 yang berjumlah 147 perusahaan.Metode penentuan sampel yang akan digunakan pada penelitian ini adalah metode non probability sampling dengan teknik purposive sampling. Teknik analisis data yang digunakan dalam penelitian ini adalah regresi logistik. 
Penelitian ini menggunakan regresi logistik karena variabel terikat atau dependennya merupakan variable dummy. Model regresi logistik yang digunakan dalam penelitian ini adalah sebagai berikut:

$\operatorname{Ln} \frac{\text { SWITCH }}{1-S W I T C H}=\propto+\beta_{1} X_{1}+\beta_{2} X_{2}+\beta_{3} X_{3}+\beta_{4} X_{1} X_{3}+\beta_{5} X_{2} X_{3}+e$

Keterangan:

$\begin{array}{ll}\text { SWITCH } & =\text { Auditor Switching } \\ \alpha & =\text { Konstanta } \\ \beta_{1-} \beta_{5} & =\text { Koefisien Regresi } \\ \mathrm{X}_{1} & =\text { Opini Audit } \\ \mathrm{X}_{2} & =\text { Audit Delay } \\ \mathrm{X}_{3} & =\text { Karakteristik Komie Audit } \\ \mathrm{E} & =\text { error }\end{array}$

\section{HASIL DAN PEMBAHASAN}

Statistik deskriptif berttujuan untuk memberikan gambaran atau deskripsi tentang variabel-variabel penelitian dari suatu data yang mencakup jumlah sampel, nilai rata-rata (mean), nilai maksimum, nilai minimum, dan standar diviasi dari masing-masing variabel. Berdasarkan pengolahan data SPSS tentang pengujian statistik deskriptif mengenai variabel opini audit, audit delay, auditor switching, serta keahlian akuntansi dan keuangan komite audit, didapatkan hasil analisis yang disajikan dalam Tabel 1 .

Tabel 1. Hasil Statistik Deskriptif

\begin{tabular}{lccccc}
\hline & $\mathrm{N}$ & Minimum & Maksimum & Mean & $\begin{array}{c}\text { Std. } \\
\text { Deviation }\end{array}$ \\
\hline Pergantian & 120 & 0,00 & 1,00 & 0,3750 & 0,48615 \\
Auditor & 120 & 0,00 & 1,00 & 0,7667 & 0,42473 \\
Opini Audit & 120 & 40,00 & 132,00 & 79,9833 & 13,07765 \\
Audit Delay & 120 & 0,33 & 1,00 & 0,7087 & 0,23709 \\
Komite & & & & & \\
Audit & 120 & & & & \\
Valid N & Listwise) & & & & \\
\hline
\end{tabular}

Sumber: Data Penelitian, 2019

Nilai minimum variabel auditor switching (AS) adalah 0 , nilai maksimum sebesar 1, standar deviasi sebesar 0,48615, dan nilai rata-rata (mean) sebesar 0,3750. Nilai mean sebesar 0,3750 menunjukkan bahwa dari 120 sampel pengamatan, perusahaan yang melakukan pergantian auditor lebih sedikit dibandingkan dengan perusahaan yang tidak melakukan pergantian auditor.

Nilai minimum variabel opini audit (OA) adalah 0 , nilai maksimum sebesar 1, standar deviasi sebesar 0,42473, dan nilai rata-rata (mean) sebesar 0,7667. Nilai mean sebesar 0,7667 menunjukkan bahwa dari 120 sampel pengamatan, perusahaan yang menerima opini audit selain wajar tanpa pengecualian lebih sedikit daripada perusahaan yang menerima opini wajar tanpa pengecualian.

Nilai minimum variabel audit delay (AD) adalah 40, nilai maksimum sebesar 132, standar deviasi sebesar 13,07765, dan nilai rata-rata (mean) sebesar 79,9833. Nilai mean sebesar 79,9833 menunjukkan bahwa dari 120 sampel pengamatan, audit delay yang dialami perusahaan lebih tinggi. 
Nilai minimum variabel keahlian akuntansi dan keuangan komite audit (KAK) adalah 0,33, nilai maksimum sebesar 1,00, standar deviasi sebesar 0,23709 dan nilai rata-rata (mean) sebesar 0,7087. Nilai mean sebesar 0,7087 menunjukkan bahwa dari 120 sampel pengamatan, lebih banyak perusahaan yang memiliki komite audit dengan anggota yang berkeahlian akuntansi dan keuangan.

Statistik yang digunakan berdasarkan pada fungsi likelihood. Penurunan likelihood (-2LL) menunjukkan model regresi yang lebih baik atau dengan kata lain model yang dihipotesiskan fit dengan data. Pengujian dilakukan dengan membandingkan nilai antara -2 Log Likelihood (-2LL) pada awal (Block Number $=$ 0 ) dengan -2 Log Likelihood (-2LL) pada akhir (Block Number =1). Hasil pengujian ditampilkan dalam Tabel 2 sebagai berikut:

Tabel 2. Overall Model Fit

\begin{tabular}{rc}
\hline -2LL awal (Block Number $=0)$ & 158,775 \\
\hline -2LL akhir (Block Number $=1)$ & 98,500 \\
\hline Sumber: Data Penelitian, 2019
\end{tabular}

Sumber: Data Penelitian, 2019

Berdasarkan Tabel 2 dapat dilihat bahwa nilai -2 Log Likelihood (-2LL) awal (Block Number $=0$ ) adalah sebesar 158,775 dan setelah dimasukkan variabelvariabel independen, maka nilai -2 Log Likelihood (-2LL) akhir (Block Number $=1$ ) mengalami penurunan menjadi 98,500. Penurunan nilai -2LL ini menunjukkan model regresi yang lebih baik atau dengan kata lain model yang dihipotesiskan fit dengan data.

Kelayakan model regresi dinilai dengan menggunakan Hosmer and Lemeshow's Goodness of Fit Test.Hosmer and Lemeshow's Goodness of Fit Test menguji hipotesis nol bahwa data empiris cocok atau sesuai dengan model (tidak ada perbedaan antara model dengan data sehingga model dapat dikatakan fit). Pengukuran ini dilakukan dengan melihat nilai Chi Square. Berikut hasil pengujian yang ditampilkan dalam Tabel 3.

Tabel 3. Hasil Uji Hosmer and Lemeshow's Test

\begin{tabular}{cccc}
\hline Step & Chi-square & df & Sig \\
\hline 1 & 10,048 & 8 & 0,262 \\
\hline
\end{tabular}

Sumber: Data Penelitian, 2019

Berdasarkan Tabel 3 maka dapat diketahui bahwa nilai statistik dari uji Hosmer and Lemeshow's yang diukur dengan nilai Chi Square sebesar 10,084 dengan nilai signifikansi sebesar 0,262 . Hal ini menunjukkan nilai signifikansi 0,262 lebih besar dari 0,05 sehingga dapat disimpulkan bahwa model dapat diterima karena cocok dengan data observasinya. Hasil ini juga menunjukkan bahwa model dikatakan fit dan model dapat diterima karena cocok dengan data yang sebenarnya.

Nagelkerke's $R$ Squaremerupakan modifikasi dari koefisien Cox dan Snell untuk memastikan bahwa nilainya bervariasi dari 0 (nol) sampai 1 (satu). Nilai yang kecil berarti kemampuan variabel-variabel independen dalam menjelaskan variasi variabel dependen terbatas. Nilai yang mendekati satu berarti variabelvariabel independen memberikan hampir semua informasi yang dibutuhkan untuk memprediksi variasi variabel dependen. Berikut ini hasil pengujian koefisien determinasi (Nagelkerke's R Square) yang disajikan dalam Tabel 4. 
Tabel 4. Hasil Uji Nagelkerke's R Square

\begin{tabular}{cccc}
\hline Step & -2 Log likelihood & $\begin{array}{c}\text { Cox \& Snell R } \\
\text { Square }\end{array}$ & $\begin{array}{c}\text { Nagelkerke } R \\
\text { Square }\end{array}$ \\
\hline 1 & 98,500 & 0,395 & 0,538 \\
\hline
\end{tabular}

Sumber: Data Penelitian, 2019

Berdasarkan Tabel 4 dapat dilihat bahwa nilai Nagelkerke's $R$ Squareyaitu sebesar 0,538 atau sama dengan 53,8\%. Angka ini berarti variabilitas variabel dependen yang dapat dijelaskan oleh variabel independen dalam penelitian ini adalah sebesar 53,8\%, sedangkan sisanya sebesar 46,2,8\% dijelaskan oleh variabelvariabel lain yang tidak disebutkan dalam model penelitian.

Matriks klasifikasi menunjukkan kekuatan prediksi dari model regresi untuk memprediksi kemungkinan terjadinya auditor switching yang dilakukan oleh perusahaan sektor manufaktur yang terdaftar di Bursa Efek Indonesia (BEI) periode 2013-2017. Berikut ini hasil uji matriks klasifikasi yang disajikan dalam Tabel 5.

\section{Tabel 5. Hasil Uji Matriks Klasifikasi}

\begin{tabular}{|c|c|c|c|c|}
\hline \multirow{3}{*}{\multicolumn{2}{|c|}{ Observed }} & \multicolumn{3}{|c|}{ Predicted } \\
\hline & & \multicolumn{2}{|c|}{ Auditor Switching } & \multirow[t]{2}{*}{ Percentage Correct } \\
\hline & & 0 & 1 & \\
\hline \multirow[t]{3}{*}{ Step 1} & Auditor Switching & 70 & 5 & 93,3 \\
\hline & & 16 & 29 & 64,4 \\
\hline & Overall Percentage & & & 82,5 \\
\hline
\end{tabular}

Sumber: Data Penelitian, 2019

Berdasarkan tabel 5 kemampuan memprediksi model regresi untuk kemungkinan perusahaan melakukan auditor switching adalah sebesar 64,4\%. Sehingga dapat diketahui bahwa dengan menggunakan model regresi tersebut, terdapat sebanyak 29 perusahaan atau $64,4 \%$ yang diprediksi akan melakukan auditor switchingdari total 45 perusahaan yang melakukan auditor switching. Sedangkan kemampuan memprediksi model regresi untuk kemungkinan perusahaan tidak melakukan auditor switching adalah sebesar 93,3\%. Sehingga dapat diketahui dengan menggunakan model regresi tersebut terdapat sebanyak 70 perusahaan atau 93,3\% yang diprediksi tidak melakukan auditor switching dari total 75 perusahaan yang tidak melakukan auditor switching

Nilai koefisien regresi dan signifikansi ditunjukkan dari model regresi yang terbentuk. Berikut ini hasil pengujian model regresi yang terbentuk disajikan dalam Tabel 6.

Tabel 6. Variable In The Equation

\begin{tabular}{cccccccc}
\hline & & B & S.E. & Wald & Df & Sig & Exp(B) \\
\hline Step 1 & X1 & $-7,389$ & 3,214 & 5,285 & 1 & 0,022 & 0,001 \\
& X2 & 0,358 & 0,133 & 7,227 & 1 & 0,007 & 1,430 \\
& X3 & 21,640 & 12,565 & 2,966 & 1 & 0,085 & $2501 \mathrm{E}$ \\
& X1.X3 & 4,904 & 3,570 & 1,887 & 1 & 0,170 & 134,8 \\
& X2.X3 & $-3,45$ & 0,163 & 4,437 & 1 & 0,034 & 0,708 \\
& Constant & $-21,899$ & 9,697 & 5,100 & 1 & 0,024 & 0,000 \\
\hline
\end{tabular}

Sumber: Data Penelitian, 2019

Berdasarkan Tabel 6 di atas, maka model regresi yang terbentuk adalah sebagai berikut: 


$$
\begin{aligned}
\operatorname{Ln} \frac{P(Y)}{1-P(Y)}= & -21,899-7,389 X 1+0,133 X 2+21,640 X 3+4,904 X 1 . X 3 \\
& -0,345 X 2 . X 3
\end{aligned}
$$

Hasil penelitian membuktikan bahwa opini audit berpengaruh negatif pada pergantian auditor. Opini audit merupakan informasi penting bagi pemegang saham atau pihak lain yang berkepentingan dengan perusahaan. Teori agensi menjelaskan bahwa manajemen sebagai pengelola perusahaan memiliki tanggungjawab atas wewenang yang telah diberikan oleh pihak pemegang saham. Pertanggung jawaban pihak manajemen dapat dinyatakan melalui laporan keuangan yang telah dibuat dan laporan audit yang dibuat merupakan penilaian independen atas laporan keuangan tersebut. Opini yang dikeluarkan oleh auditor sebagai bentuk penilaian atas laporan keuangan apat mempengaruhi pandangan dari para pemegang saham terhadap kinerja dari manajemen selaku penglola perusahaan.

Perusahaan atau pihak manajemen akan cenderung untuk menghindari opini audit yang tidak diinginkan. Penelitian dari Chow dan Rice (1982) menyatakan perusahaan pada umumnya berganti KAP sesudah menerima qualified opinion atas laporan keuangannya. Artinya apabila perusahaan menerima opini yang tidak diharapkan atas laporan keuangannya akan cenderung melakukan pergantian auditor. Sebaliknya perusahaan akan mempertahankan auditornya, ketika menerima opini wajar tanpa pengecualian atas laporan keuangannya. Hal ini dikarenakan perusahaan cenderung menghindari munculmya qualified opinion yang dapat menurunkan kredibilitas laporan keuangan perusahaan serta dianggap akan memberikan respon negatif pada harga saham. Hal tersebut menyebabkan manajemen perusahaan akan memberhentikan auditornya karena memberikan opini audit yang tidak diharapkan dan akan mencari auditor yang lebih mudah diatur (Carcello dan Neal, 2003).

Hasil penelitian ini didukung oleh penelitian Wahyuningsih dan Suryanawa (2012), Salim dan Rahayu (2014) serta Putra dan Suryanawa (2016), yang menyatakan bahwa opini audit berpengaruh negatif pada pergantian auditor.

Hasil penelitian berhasil membuktikan bahwa audit delay berpengaruh positif terhadap terjadinya pergantian auditor. Penelitian ini mendukung temuan Stocken (2000) dalam Srimindarti (2006) yang menyatakan bahwa penyelesaian tugas audit yang terlalu lama dapat menyebabkan perusahaan terlambat menyampaikan laporan keuangan ke pasar modal sehingga berpengaruh pada pergantian auditor.

Keterlambatan audit atau audit delay adalah lamanya waktu yang dibutuhkan oleh auditor untuk mengaudit laporan keuangan sejak tanggal tutup buku perusahaan hingga diterbitkannya laporan audit (Shulthoni, 2012). Audit delay yang panjang dipengaruhi oleh kerumitan proses audit yang dilakukan oleh auditor. Tingkat kerumitan yang tinggi ini dapat mengakibatkan seorang auditor dalam melaksanakan proses auditnya memerlukan jumlah hari yang 
lebih banyak untuk mengaudit perusahaan induk beserta anak perusahaannya (Che-Ahmad dan Abidin, 2009).

Panjang-pendeknya audit delay menjadi penentu ketepatwaktuan perusahaan dalam mempublikasikan laporan keuangan ke pasar modal. Ketepatwaktuan dalam mempublikasi laporan keuangan menjadi hal penting yang perlu diperhatikan oleh perusahaan, karena dengan ini publik dapat menilai kinerja perusahaan apakah dalam kondisi baik atau buruk. Informasi keuangan yang terdapat dalam laporan keuangan tersebut dapat menjadi bahan pertimbangan bagi investor untuk menanamkan modalnya ke perusahaan tersebut. Apabila terjadi keterlambatan, maka publik akan mencurigai bahwa perusahaan tersebut sedang mengalami masalah yang akan berpengaruh pada keputusan stakeholders dan harga saham perusahaan. Tentu saja perusahaan tidak ingin keterlambatan publikasi laporan keuangan yang disebabkan oleh audit delay terjadi lagi di tahun berikutnya, sehingga pada tahun berikutnya perusahaan akan melakukan voluntary auditor switching.

Hasil pengujian variabel opini audit dengan komite audit sebagai variabel pemoderasi menunjukkan tingkat signifikansi 0,128 $>0,05$ yang menunjukkan bahwa komite audit tidak mampu memoderasi hubungan opini audit pada pergantian auditor sehingga dapat disimpulkan bahwa $\mathrm{H}_{3}$ ditolak dan $\mathrm{H}_{0}$ diterima.

Karakteristik keahlian akuntansi dan keuangan komite audit tidak mampu memoderasi pengaruh opini audit pada terjadinya pergantian auditor. Keahlian akuntansi dan keuangan komite audit merupakan hal yang wajib dimiliki dimana komite audit diharapkan dapat menjaga integritas proses pelaporan laporan keuangan. Komite auditlah yang memiliki tugas untuk memberikan rekomendasi dalam melakukan penunjukkan dan penggantian auditor. Namun masih adanya peran manajemen yang masih cukup kuat dalam hal ini menyebabkan keberadaan komite audit tidak dapat mencegah manajemen dalam melakukan pergantian auditor.

Hasil penelitian ini sejalan dengan penelitian Carcello dan Neal (2003) dan Esfandari, (2011). Hasil ini juga konsisten dengan penelitian Adhiputra, (2015) dan yang menemukan bahwa keahlian akuntansi dan keuangan komite audit tidak memiliki pengaruh pada kemungkinan perusahaan melakukan pergantian auditor.

Hasil uji regresi logistik menunjukkan bahwa komite audit mampu memoderasi dan memperlemah pengaruh audit delay pada pergantian auditor. Hasil ini sangat terkait dengan hasil penelitian yang dilakukan oleh Artawijaya dan Putri (2016) yang menyatakan bahwa keahlian akuntansi dan keuangan komite audit berpengaruh negatif pada pergantian auditor. Keahlian akuntansi dan keuangan yang dimiliki oleh komite audit dapat mencegah dan memberikan solusi kepada manajemen untuk tidak melakukan pergantian auditor.

Penelitian dari DeZoort dan Salterio (2001) memberikan bukti bahwa komite audit dengan keahlian akuntansi dan keuangan memiliki kemungkinan yang lebih tinggi mendukung auditor dalam perselisihan dengan manajemen perusahaan. Anggota komite audit yang ahli akuntansi dan keuangan akan lebih efektif mengawasi pelaporan keuangan perusahaan dan proses audit sehingga terjadinya pergantian auditor akibat terjadinya keterlambatan penyampaian 
laporan auditjuga dapat dicegah. Penelitian Owens-Jackson et al., (2009) juga menemukan bahwa keahlian akuntansi dan keuangan berpengaruh pada kecenderungan berkurangnya pergantian auditor.

Dari hasil uji statistik untuk pengujian $\mathrm{H}_{2}$ didapat bahwa audit delay berpengaruh positif pada pergantian auditor. Dengan adanya moderasi komite audit, maka didapat bahwa pengaruh audit delay pada pergantian auditor menjadi berkurang. Manajemen perusahaan yang mengalami audit delay cenderung akan melakukan pergantian auditor agar hal serupa tidak terjadi lagi. Dalam peranannya sebagai mekanisme corporate governance, komite audit akan berusaha untuk mencegah manajemen melakukan pergantian auditor ketika perusahaan mengalami keterlambatan penyampaian laporan auditan. Hal ini disebabkan karena dengan kondisi perusahaan yang mengalami audit delayperlu meningkatkan kepercayaan investor terhadap perusahaan, sehingga jika perusahaan melakukan pergantian auditor, hal tersebut akan lebih mengurangi kepercayaan investor terhadap perusahaan. Sehingga dapat disimpulkan bahwa komite audit memperlemah pengaruh audit delay pada pergantian auditor.

\section{SIMPULAN}

Opini audit berpengaruh negatif pada auditor switching. Hal ini berarti semakin sering perusahaan memperoleh opini audit diluar opini wajar tanpa pengecualian maka perusahaan cenderung akan melakukan pergantian auditor. Audit delay berpengaruh positif pada auditor switching. Semakin panjang audit delay maka kecenderungan perusahaan untuk melakukan pergantian auditor akan ssemakin tinggi. Komite audit dengan keahlian akuntansi dan keuangan tidak mampu memoderasi pengaruh opini audit pada pergantian auditor. Keberadaan komite audit dengan keahlian akuntansi dan keuangan belum mampu mencegah terjadinya pergantian auditor ketika perusahaan menerima opini audit yang tidak diinginkan perusahaan. Komite audit dengan keahlian akuntansi dan keuangan mampu memperlemah pengaruh audit delay pada auditor switching. Hal ini berarti bahwa keahlian akuntansi dan keuangan yang dimiliki oleh komite audit dapat mengawasi dan memberi solusi dengan baik untuk mencegah terjadinya pergantian auditor ketika perusahaan mengalami audit delay.

\section{REFERENSI}

Adhiputra. (2015). Pengaruh Penerbitan Opini Going Concern pada Pergantian Auditor pada Perusahaan yang Terdaftar pada Bursa Efek Indonesia. Jurnal Dinamika Akuntansi, 7(1).

Alansari, P. (2016). Opini Audit Going Concern Sebagai Pemoderasi Pengaruh Pertumbuhan Perusahaan danPergantian Manajemen Pada Auditor Switching. E-Jurnal Akuntansi Universitas Udayana, 15.

AlAzhar L. (2015). Influence of Financial Distress, Management Turnover and Audit Opinion to Auditor Switching (Empirical Study on Manufacturing Companies Listed on The BEI During 2011-2013 Period). Research Journal of Finance and Accounting, 6(24).

Arma, E. U. (2013). Pengaruh Profitabilitas, Likuiditas, dan Pertumbuhan Perusahaan Terhadap Penerimaan Opini Audit Going Concern (Studi 
Empiris Perusahaan Manufaktur yang Terdaftar Pada Bursa Efek Indonesia). Jurnal Universitas Negeri Padang.

Artawijaya, I. G. N., \& Putri, I. G. A. M. A. D. (2016). Pengaruh Opini Audit Going Concern dan Karakteristik Komite Audit pada Pergantian Auditor. EJurnal Akuntansi Universitas Udayana, 16(3), 1716-1743.

Carcello, J. V., \& Neal, T. L. (2003). Audit Committee Characteristics and Auditor Dismissals Following "New" Going-Concern Reports. Accounting Review.

Che-Ahmad, A., \& Abidin, S. (2009). Audit Delay of Listed Companies: A Case of Malaysia. International Business Research, 1(4).

Chow, C. W., \& Rice, S. J. (1982). Qualified Audit Opinions and Auditor Switching. Source: The Accounting Review, 57(2), 326-335.

Chrisanty, Y. D. (2010). Analisis Faktor-Faktor yang Mempengaruhi Ketepatanwaktu Penyampaian Laporan Keuangan. Diponegoro Journal of Accounting.

DeZoort, F. T., \& Salterio, S. E. (2001). The Effects of Corporate Governance Experience and Financial-Reporting and Audit Knowledge on Audit Committee Members' Judgments. Auditing, 20(2), 31-47.

Esfandari, A. Y. (2011). Kompetensi Komite Audit Sebagai Pemoderasi Hubungan Antara Penerbitan Opini Going Concern dengan Pergantian Auditor. Tesis. Universitas Gadjah Mada.

Febrianty. (2011). Faktor-Faktor yang Berpengaruh Terhadap Audit Delay Perusahaan Sektor Perdagangan Yang Terdaftar di BEI Periode 2007-2009. Jurnal Ekonomi Dan Informasi Akuntansi (JENIUS), 1(3), 294-320.

Giri, E. F. (2010). Pengaruh Tenur Kantor Akuntan Publik ( KAP ) Dan Reputasi KAP terhadap Kualitas Audi: Kasus Rotasi Wajib Auditor di Indonesia. Prosiding Simposium Nasional Akuntansi XIII Purwokerto, 1-26.

Jensen, M., \& Meckling, W. (1976). Theory of the firm: Managerial behaviour, agency costs and ownership. Strategic Management Journal, 21(4), 1215-1224.

Kristiana, I. (2012). Pengaruh Ukuran Perusahaan, Profitabilitas, Likuiditas, Pertumbuhanperusahaan Terhadap Opini Audit Going Concern pada Perusahaan Manufaktur yang Terdaftar di Bursa Efek Indonesia (BEI). Berkala Ilmiah Mahasiswa Akuntansi, 1(1).

Lennox, C. S. (2002). Opinion Shopping and Audit Committees. CEI Working Paper Series, 2002-12.

Lin, Z. J., \& Liu, M. (2010). The determinants of auditor switching from the perspective of corporate governance in China. Advances in Accounting, 26(1), 117-127.

Mas, Farida Ruroh. (2016). Pengaruh Pergantian Manajemen, Kesulitan Keuangan, Ukuran KAP, dan Audit Delay Terhadap Auditor Switching (Studi Kasus pada Perusahaan Manufaktur yang Terdaftar di Bursa Efek Indonesia tahun 2012-2015). IOSR Journal of Economics and Finance, 3(1), 56.

Merawati, L. K. (2014). Peran Karakteristik Komite Audit dan Reputasi Auditor dalam Meningkatkan Kualitas Audit (Studi Empiris pada Perusahaan Manufaktur yang Mengganti Auditornya Secara Sukarela Tahun 2008-2011). Jurnal Buletin Studi Ekonomi, 19(2), 148-157.

Merawati, L. K., Badera, I. D. N., \& Suardikha, I. M. S. (2013). Pengaruh 
Karakteristik Komite Audit pada Hubungan Opini Audit Going Concern dengan Pergantian Auditor. Simposium Nasional Akuntansi XVI Manado, (September 2013), 25-28.

Nikmah, L. (2014). Analisis Faktor-Faktor yang Mempengaruhi Pergantian Auditor. Diponegoro Journal of Accounting, 3.

Nuratama, I. P. (2011). Pengaruh Tenur Dan Reputasi Kantor Akuntan Publik Pada Kualitas Audit Dengan Komite Audit Sebagai Variabel Moderasi. Tesis. Program Pascasarjana Universitas Udayana Denpasar 2013.

Owens-Jackson, L. A., Robinson, D., \& Shelton, S. W. (2009). The Association Between Audit Committee Characteristics, the Contracting Process and Fraudulent Financial Reporting. American Journal of Business (Emerald Group Publishing Limited), 24(1), 57.

Paramita. (2015). Pengaruh Ukuran Perusahaan, Umur Publikasi, Masa Perikatan Audit, Pergantian Manajemen Pada Kualitas Audit. Jurnal Akuntansi Universitas Udayana, 13.

Pawitri, N. M. P., \& Yadnyana, K. (2015). Pengaruh Audit Delay , Opini Audit, Reputasi Auditor Dan Pergantian Manajemen Pada Voluntary Auditor Switching. E-Jurnal Akuntansi Universitas Udayana, 1(10), 214-228.

Peranian, N. A., \& Mimba, N. P. S. H. (2018). Pengaruh Good Corporate Governance, Financial Distress, dan Return On Equity pada Voluntary Auditor Switching. E-Jurnal Akuntansi Universitas Udayana, 23, 1574-1599.

Permata Sari, G. A. A. I., \& Astika, I. B. P. (2018). Pengaruh Opini Going Concern, Financial Distress dan Kepemilikan Institusional pada Auditor Switching. EJurnal Akuntansi, 898.

Prasetyo, A. B. (2016). Pengaruh Karakteristik Komite Audit, Perusahaan dan Struktur Kepemilikan Terhadap Kecurangan Pelaporan Keuangan. SAR (Soedirman Accounting Review) : Journal of Accounting and Business, 1(1), 50.

Pratini, I. G. A. A. I. . P. A. (2013). Fenomena Pergantian Auditor di Bursa Efek Indonesia. E-Jurnal Akuntansi Universitas Udayana 5.2, 2, 470-482.

Purwoningsih, R. B. (2016). Pengaruh Opini Audit Going Concern, Audit Delay, Aktivitas Komite Audit, Pertumbuhan Perusahaan Terhadap Pergantian Auditor dengan Keahlian Keuangan dan Akuntansi Komite Audit Sebagai Variabel Moderasi. Jurnal Akuntansi Universitas Muhammadiyah Yogyakarta.

Putra, I. G. B. B. P., \& Suryanawa, I. K. (2016). Pengaruh Opini Audit dan Reputasi KAP Pada Auditor Switching dengan Financial Distress Sebagai Variabel Moderasi. E-Jurnal Akuntansi Universitas Udayana, 14(2).

Ramantha, I. W. (2014). Pengaruh Audit Fee, Opini Going Concern , Financial Distress Dan Ukuran Perusahaan Pada. E-Jurnal Ankuntansi, 3(7), 663-676.

Riyandari, P. K., \& Badera, I. D. N. (2017). Pengalaman Auditor Sebagai Pemoderasi Pengaruh Time Budget Pressure dan Kompleksitas Audit Pada Kualitas Audit. ISSN: 2302-8556. Bali: E-Jurnal Universitas Udayana, Vol. 19(No. 1), 195-222.

Robbitasari, A. P., \& Wiratmaja, I. D. N. (2013). Pengaruh Opini Audit Going Concern, Kepemilikan Institusional dan Audit Delay Pada Voluntary Auditor Switching. E-Jurnal Akuntansi Universitas Udayana 5.3, 652-665.

Rustiarini. (2012). Komite Audit dan Kualitas Audit: Kajian Berdasarkan Karakteristik, Kompetensi dan Efektivitas Komite Audit. Simposium Nasional 
Akuntansi XV. Banjarmasin.

Salim, A., \& Rahayu, S. (2014). Pengaruh Opini Audit, Ukuran KAP, Pergantian Manajemen, Dan Financial Distress terhadap Auditor Switching (Studi Kajian pada Perusahaan Manufaktur yang Terdaftar di Bursa Efek Indonesia Tahun 2008-2012). E-Proceeding of Management, 1(3), 388-400.

Setiawan, S. (2006). Opini Going Concern dan Prediksi Kebangkrutan Perusahaan. Jurnal Ilmiah Akuntansi, 5.

Shulthoni, M. (2012). Determinan Audit Delay dan Pengaruhnya Terhadap Reaksi Investor (Studi Empiris pada Perusahaan yang Listing di BEI Tahun 2007-2008). Jurnal Akuntansi Dan Ekonomi Bisnis, 1(1), 55-71.

Srimindarti, C. (2006). Opini Audit Dan Pergantian Auditor: Kajian Berdasarkan Resiko, Kemampuan Perusahaan Dan Kinerja Auditor. Fokus Ekonomi, 5(1), 64-76.

Stocken, M. E. (2000). Auditor Conservatism and Opinion Shopping: Influence of Client Switching Expectations on Audit Opinion Decision. Dissertation Unpublished.

Tisna, N. W. W., \& Suputra, I. D. G. D. (2017). Financial Distress Sebagai Pemoderas Pangaruh Opini Audit dan Pertumbuhan Perusahaan Pada Auditor Switching. Jurnal Akuntansi Universitas Udayana, 19(3), 2118-2144.

Verawati, N. M. A., \& Wirakusuma, M. G. (2016). Pengaruh Pergantian Auditor, Reputasi KAP, Opini Audit Dan Komite Audit Terhadap Audit Delay. Jurnal Akuntansi Universitas Udayana, 17(2), 2302-8556.

Wahyuningsih, N., \& Suryanawa, I. K. (2012). Analisis Pengaruh Opini Audit Going Concern dan Pergantian Manajemen pada Auditor Switching. Jurnal Ilmiah Akuntansi Dan Bisnis, 7(1), 1-20. 